\title{
STATISTICAL-MATHEMATICAL PROCESSING OF ANTHROPOMETRIC FOOT PARAMETERS AND ESTABLISHING SIMPLE AND MULTIPLE CORRELATIONS. PART 2: CORRELATIONS AMONG ANTHROPOMETRIC PARAMETERS OF THE FOOT
}

\author{
Mirela PANTAZI ${ }^{1 *}$, Ana Maria VASILESCU ${ }^{1}$, Aura MIHAI², Dana GURĂU ${ }^{1}$ \\ ${ }^{1}$ INCDTP - Division: Leather and Footwear Research Institute, 93 Ion Minulescu, 031215 Bucharest, Romania, pantazimirela@
} yahoo.com

2“Gheorghe Asachi” Technical University of lasi, 67 Dimitrie Mangeron Blvd., lasi, Romania, amihai@tex.tuiasi.ro

Received: 03.10.2017

Accepted: 21.02 .2018

https://doi.org/10.24264/Ifj.18.1.3

STATISTICAL-MATHEMATICAL PROCESSING OF ANTHROPOMETRIC FOOT PARAMETERS AND ESTABLISHING SIMPLE AND MULTIPLE CORRELATIONS. PART 2: CORRELATIONS AMONG ANTHROPOMETRIC PARAMETERS OF THE FOOT

ABSTRACT. Footwear manufacturing based on suitable lasts and appropriate sizes is possible, using the results obtained from anthropometric measurements. The construction of the last, the establishment of dimensions required to meet the comfort requirements of a larger proportion of consumers, must be based on the knowledge and the most accurate characterization of the anatomical-morphological differences of the types of foot encountered within that population of consumers as well as the frequency of these types within the population. For this purpose, it is periodically necessary to perform anthropometric studies on the population differentiated according to certain criteria (gender, age, geographical region, etc.) in order to obtain information about the dimensional particularities of the average representative foot for that population, the anthropometric parameters distribution laws that characterize the representative average foot of the country's population in terms of size. In order to define the characteristic dimensions of the foot, one- and two-dimensional distributions of anthropometric parameters were used as well as a series of correlations that model the interdependence among the various parameters, with direct applicability in designing the last. Linear regression equations can be used in last design to determine the dependences between the geometric parameters of the last in close connection with the laws of variation of the anthropometric parameters of the foot. Multiple linear correlations have been established demonstrating that there are very high correlations between certain variables.

KEY WORDS: anthropometric parameters, foot, correlation

\section{PRELUCRAREA STATISTICO-MATEMATICĂ A PARAMETRILOR ANTROPOMETRICI AI PICIORULUI ŞI STABILIREA CORELATIILOR SIMPLE Ş MULTIPLE. PARTEA 2: CORELATII ÎNTRE PARAMETRII ANTROPOMETRICI AI PICIORULUI}

REZUMAT. Realizarea de încălţăminte pe calapoade adecvate, într-un pontaj corespunzător, este posibilă, prin utilizarea rezultatelor obţinute prin măsurători antropometrice. Construcţia calapodului, stabilirea tipodimensiunilor necesare satisfacerii cerinţelor de confort a unei ponderi cât mai mari de consumatori, trebuie să aibă la bază cunoaşterea şi caracterizarea cât mai exactă a diferenţelor de ordin anatomo-morfologic a tipurilor de picior care se întâlnesc în cadrul acelei populaţii de consumatori precum şi a frecvenţei acestor tipuri în cadrul populaţiei. În acest scop, periodic, este necesară efectuarea unor studii antropometrice asupra populaţiei diferenţiate după anumite criterii (sex, vârstă, regiune geografică etc.) în scopul obţinerii unor informaţii privind particularităţile dimensionale ale piciorului mediu reprezentativ pentru acea populaţie, legile de distribuţie a parametrilor antropometrici ce caracterizează sub raport dimensional piciorul mediu reprezentativ al populaţiei ţării respective. În vederea definirii tipodimensiunilor caracteristice ale piciorului, s-au utilizat distribuţii uni şi bidimensionale ale parametrilor antropometrici precum şi o serie de corelaţii ce modelează interdependenţa dintre diverşi parametri, având aplicabilitate directă în proiectarea calapodului. Ecuaţiile de regresie de tip liniar pot fi folosite la proiectarea calapoadelor pentru stabilirea dependenţelor dintre parametrii geometrici ai calapodului în strânsă legătură cu legile de variaţie a parametrilor antropometrici ai piciorului. S-au stabilit corelaţii multiple de tip liniar care demonstrează că există corelaţii foarte ridicate între anumite variabile.

CUVINTE CHEIE: parametri antropometrici, picior, corelaţie

LE TRAITEMENT STATISTIQUE-MATHÉMATIQUE DES PARAMÈTRES ANTROPOMÉTRIQUES DU PIED ET LA DÉTERMINATION DES CORRÉLATIONS SIMPLES ET MULTIPLES. DEUXIÈME PARTIE: DES CORRÉLATIONS ENTRE LES PARAMÈTRES ANTROPOMÉTRIQUES DU PIED RÉSUMÉ. La fabrication des chaussures à partir d'une forme et des dimensions appropriées est possible en utilisant les résultats obtenus par des mesures anthropométriques. La construction de la forme, l'établissement des tailles standard pour satisfaire les exigences de confort pour la majorité des consommateurs, doivent être fondés sur la connaissance et la caractérisation plus exacte des différences anatomiques et morphologiques des types du pied rencontrés chez cette population des consommateurs, ainsi que la fréquence de ces types au sein de la population. A cet effet, périodiquement, il est nécessaire de mener des études anthropométriques sur la population différenciée selon certains critères (sexe, âge, région géographique, etc.) afin d’obtenir des informations sur les particularités dimensionnelles du pied représentatif pour la population, les lois de distribution des paramètres anthropométriques qui caractérisent le pied moyen représentatif de la population du pays. Pour définir les tailles standard caractéristiques du pied, on a utilisé des distributions uni- et bidimensionnelles des paramètres anthropométriques ainsi qu'un certain nombre de corrélations qui déterminent l'interdépendance entre les différents paramètres, avec application directe dans la conception de la forme. Les équations de régression linéaire peuvent être utilisées pour concevoir les formes de chaussures et pour définir les dépendances entre les paramètres géométriques de la forme en étroite collaboration avec les lois de variation des paramètres anthropométriques du pied. Des corrélations multiples ont été établies, démontrant qu'il existe des corrélations très élevées entre certaines variables.

MOTS CLÉS : paramètres anthropométriques, pied, corrélation

\footnotetext{
* Correspondence to: Mirela PANTAZI, INCDTP - Division: Leather and Footwear Research Institute, 93 lon Minulescu, 031215 Bucharest, Romania, pantazimirela@yahoo.com
} 


\section{INTRODUCTION}

It is periodically necessary to perform anthropometric studies on the population differentiated according to certain criteria (sex, age, geographical region, etc.) in order to obtain information about the dimensional particularities of the average representative foot for that population, the laws of distribution of anthropometric parameters that characterize the representative average foot of the population of the respective country. In order to define characteristic dimensions of the foot, one- and two-dimensional distributions of anthropometric parameters as well as a series of correlations that model the interdependence among various parameters, with direct applicability in designing the last. The correlation between two or more anthropometric parameters is the statistical interdependence between them. The correlation involves establishing a real connection between the studied parameters, connection that may be analyzed in terms of its direction, form and intensity. Correlations among the studied anthropometric parameters are useful in the design of lasts and footwear.

\section{EXPERIMENTAL}

\section{Materials and Methods}

Using the INFOOT USB system, made up of the 3D scanner and the dedicated MEASURE 2.8 software, as a result of foot shape scanning and placement of anatomical points on the surface of the scanned foot shape, values for a set of 20 anthropometric parameters, lengths, widths, girths and angles were determined (Table 1) [1].

Table 1: Anthropometric parameters of the foot

\begin{tabular}{|c|c|c|c|}
\hline 1. & Foot length & $L p$ & $(\mathrm{~mm})$ \\
\hline 2. & Ball girth circumference & $\mathrm{Pd}$ & $(\mathrm{mm})$ \\
\hline 3. & Foot breadth & ld & $(\mathrm{mm})$ \\
\hline 4. & Instep circumference & $\operatorname{Pr}$ & $(\mathrm{mm})$ \\
\hline 5. & Heel breadth & lc & $(\mathrm{mm})$ \\
\hline 6. & Instep length & $\mathrm{Lr}$ & $(\mathrm{mm})$ \\
\hline 7. & Toe height & $\mathrm{Hd}$ & $(\mathrm{mm})$ \\
\hline 8. & Instep height & $\mathrm{Hr}$ & $(\mathrm{mm})$ \\
\hline 9. & Toe 1 angle & Ud1 & $\left({ }^{\circ}\right)$ \\
\hline 10. & Toe 5 angle & Ud5 & $\left({ }^{\circ}\right)$ \\
\hline 11. & Toe 1 height & $\mathrm{Hd} 1$ & $(\mathrm{~mm})$ \\
\hline 12. & Toe 5 height & $\mathrm{Hd} 5$ & $(\mathrm{~mm})$ \\
\hline 13. & Height of navicular & $\mathrm{Hn}$ & $(\mathrm{mm})$ \\
\hline 14. & Height of Sphyrion fibulare & Hsf & $(\mathrm{mm})$ \\
\hline 15. & Height of Sphyrion & Hs & $(\mathrm{mm})$ \\
\hline 16. & Height of the most lateral point of lateral malleolus & Hme & $(\mathrm{mm})$ \\
\hline 17. & Height of the most medial point of medial malleolus & $\mathrm{Hmi}$ & $(\mathrm{mm})$ \\
\hline 18. & Heel angle & Uc & $\left({ }^{\circ}\right)$ \\
\hline 19. & Heel girth & $\mathrm{Pc}$ & $(\mathrm{mm})$ \\
\hline 20. & Ankle girth & $\mathrm{Pg}$ & $(\mathrm{mm})$ \\
\hline
\end{tabular}

Anthropometric footprints obtained using the INFOOT USB system were statistically analyzed using the SPSS software package, which is a package dedicated to statistical data processing, making it easy to obtain the desired results quickly. Anthropometric data collected by 3D scanning of the left and right foot were grouped into four samples (South, East, Centre-
West and Total) and then statistical indicators of characterization (arithmetic mean and standard deviation) and statistical indicators of variation (minimum and maximum value, amplitude and coefficient of variation) were calculated for each variational sequence of the 20 anthropometric parameters studied. Regressions and correlations 
were established between parameters of the analyzed samples: statistical dependencies, simple linear correlations, simple non-linear correlations, multiple linear correlations.

\section{Subjects}

Anthropometric studies were conducted on a sample of 300 male subjects from three geographic regions of Romania: Dobrogea, Oltenia and Muntenia - South (100 subjects), Moldavia and Bucovina - East (100 subjects) and Transylvania and Banat - Centre and West (100 subjects). Subjects with particular anthropometric features, including deformities and structural abnormalities of the foot, were excluded.

\section{RESULTS AND DISCUSSIONS}

\section{Simple Correlations (between Two Variables) to Characterize the Interdependence of Anthropometric Parameters}

The intensity of dependence between two random variables, namely the analyzed anthropometric parameters, is quantitatively expressed by the coefficient of correlation, $r_{x y}[2,3]$ :

$$
r_{y x}=\frac{\sum_{i=1}^{n}\left(x_{i}-\bar{x}\right)\left(y_{i}-\bar{y}\right)}{n S_{x} S_{y}}
$$

where:

$\left(x_{i}-\bar{x}\right)$ si $\left(y_{i}-\bar{y}\right)$ - deviations of particular values of variables from the average;

$S_{x} S_{y}$ - mean squared deviations of variables;

$$
\mathrm{n} \text {-selection volume. }
$$

Values of coefficients of correlation between the studied anthropometric parameters are presented in Table 2. Coefficient of variation $r_{y x}$ varies in the range between -1 and +1 (Figure 1). If $r_{y x}$ is in the range $(0,1)$ then dependence between variables is direct and if $r_{y x}$ is in the range $(-1,0)$ then the connection between variables is reversed.

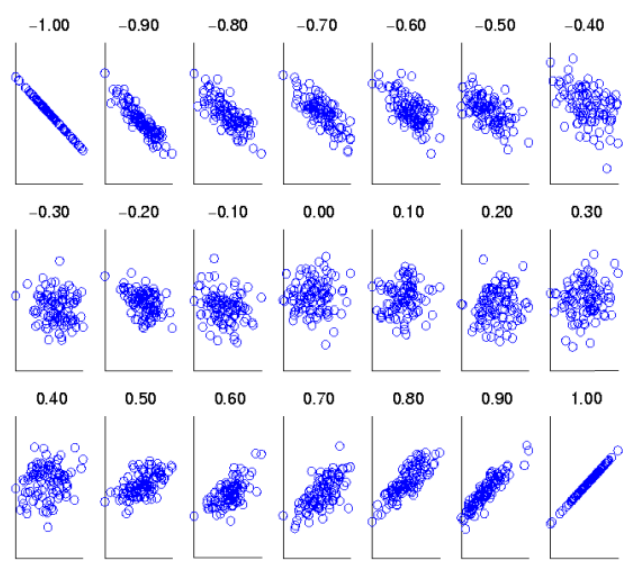

Figure 1. Graphic representation of correlations for $r_{y x}$ from -1 to +1

\begin{tabular}{|c|c|c|c|c|c|c|c|c|c|c|c|c|c|c|c|c|c|c|c|c|}
\hline & $\mathrm{LP}_{\mathrm{B}}$ & Pd & ld & $\mathrm{Pr}$ & ls & $\mathrm{Lr}$ & $\mathrm{Hd}$ & $\mathrm{Hr}$ & Ud1 & Ud5 & Hd1 & Hd5 & $\mathrm{Hn}$ & Hsf & $\mathrm{Hs}$ & Hme & Hmi & $\mathrm{Uc}_{c}$ & $\mathrm{Pc}$ & $\mathrm{Pg}$ \\
\hline LR & 1.000 & & & & & & & & & & & & & & & & & & & \\
\hline $\mathrm{Pd}$ & 0.762 & 1.000 & & & & & & & & & & & & & & & & & & \\
\hline ld & 0.651 & 0.966 & 1.000 & & & & & & & & & & & & & & & & & \\
\hline $\mathrm{Pr}$ & 0.529 & 0.827 & 0.745 & 1.000 & & & & & & & & & & & & & & & & \\
\hline Is & 0.506 & 0.622 & 0.608 & 0.590 & 1.000 & & & & & & & & & & & & & & & \\
\hline Lt & 0.939 & 0.625 & 0.638 & 0.468 & 0.445 & 1.000 & & & & & & & & & & & & & & \\
\hline Hd & 0.866 & 0.507 & 0.492 & 0.455 & 0.454 & 0.813 & 1.000 & & & & & & & & & & & & & \\
\hline $\mathrm{Hr}$ & 0.254 & 0.609 & 0.414 & 0.701 & 0.450 & 0.136 & 0.222 & 1.000 & & & & & & & & & & & & \\
\hline Ud1 & 0.003 & 0.070 & 0.160 & -0.033 & 0.017 & 0.023 & -0.108 & -0.168 & 1.000 & & & & & & & & & & & \\
\hline Ud5 & 0.009 & 0.297 & 0.329 & 0.266 & 0.089 & -0.069 & 0.051 & 0.176 & -0.061 & 1.000 & & & & & & & & & & \\
\hline Hdl & 0.254 & 0.440 & 0.315 & 0.493 & 0.462 & 0.203 & 0.280 & 0.633 & -0.117 & 0.008 & 1.000 & & & & & & & & & \\
\hline Hd5 & 0.266 & 0.453 & 0.443 & 0.405 & 0.442 & 0.229 & 0.236 & 0.352 & 0.219 & 0.147 & 0.479 & 1.000 & & & & & & & & \\
\hline $\mathrm{Hn}$ & -0.066 & 0.107 & 0.025 & 0.175 & 0.130 & -0.141 & 0.048 & 0.431 & -0.022 & 0.078 & 0.385 & 0.212 & 1.000 & & & & & & & \\
\hline Hsf. & 0.373 & 0.388 & 0.302 & 0.386 & 0.159 & 0.381 & 0.378 & 0.427 & -0.154 & 0.088 & 0.310 & 0.062 & 0.303 & 1.000 & & & & & & \\
\hline $\mathrm{Hs}$ & 0.419 & 0.405 & 0.325 & 0.318 & 0.159 & 0.419 & 0.429 & 0.380 & -0.152 & 0.042 & 0.203 & -0.072 & 0.278 & 0.824 & 1.000 & & & & & \\
\hline Hme & 0.458 & 0.438 & 0.358 & 0.403 & 0.210 & 0.453 & 0.445 & 0.426 & -0.120 & 0.072 & 0.297 & 0.040 & 0.292 & 0.954 & 0.839 & 1.000 & & & & \\
\hline Hmi & 0.481 & 0.458 & 0.380 & 0.366 & 0.193 & 0.466 & 0.476 & 0.402 & -0.140 & 0.077 & 0.209 & -0.051 & 0.237 & 0.826 & 0.973 & 0.870 & 1.000 & & & \\
\hline$U_{c}$ & 0.124 & 0.041 & 0.091 & 0.023 & -0.111 & 0.123 & -0.070 & -0.208 & 0.040 & 0.031 & -0.193 & -0.082 & -0.184 & 0.128 & 0.006 & 0.111 & 0.028 & 1.000 & & \\
\hline Pc & 0.775 & 0.767 & 0.696 & 0.760 & 0.753 & 0.699 & 0.744 & 0.628 & 0.000 & 0.113 & 0.493 & 0.455 & 0.206 & 0.401 & 0.401 & 0.463 & 0.453 & \begin{tabular}{|c|}
-0.137 \\
\end{tabular} & 1.000 & \\
\hline $\mathrm{Pg}$ & 0.693 & 0.658 & 0.581 & 0.703 & 0.587 & 0.616 & 0.671 & 0.592 & 0.050 & 0.090 & 0.474 & 0.400 & 0.227 & 0.323 & 0.319 & 0.391 & 0.381 & -0.172 & 0.897 & 1.0 \\
\hline
\end{tabular}

Table 2: Matrix of values of coefficients of correlations between anthropometric parameters

correlations:

Interpretation of coefficients of

$r_{x y}=0.2-0.4-$ Very low correlation - Orange

$r_{x y}=0.4-0.7-$ Low correlation - Green $r_{x y}=0.7-0.9-$ High correlation - Blue

$r_{x y}=0.9-1$ - Very high correlation - Yellow

Linear correlations are described by the following regression equation [3-5]: 
$\mathrm{y}=\mathrm{b} 0+\mathrm{b} 1^{\star} \mathrm{x}$

Where:

$x$ - independent variable;

$y$ - value of the dependent variable calculated by means of reaction equation;

$b_{1}, b_{0}-$ coefficients of the regression equation.
Simple linear regression equations were determined for the pairs of anthropometric parameters characterized by the coefficients of correlation higher than 0.7 (strong and very strong correlation) and are presented in Table 3 , and for exemplification, the graphic form of these equations is represented in Figures 2-15.

Table 3: Linear regression equations

\begin{tabular}{|c|c|c|c|c|}
\hline \multirow[t]{2}{*}{ No. } & \multirow{2}{*}{$\begin{array}{l}\text { Correlated variables } \\
y=f(x)\end{array}$} & \multirow[t]{2}{*}{$\mathrm{R}^{2}$} & \multicolumn{2}{|c|}{ Coefficients of equation } \\
\hline & & & $b_{0}$ & $b_{1}$ \\
\hline 1. & $I d=f(P d)$ & 0.934 & -1.864 & 0.416 \\
\hline 2. & $I d=f(P r)$ & 0.555 & 32 & 0.284 \\
\hline 3. & $L r=f(L p)$ & 0.882 & 0.446 & 0.715 \\
\hline 4. & $P d=f(L p)$ & 0.437 & 82.25 & 0.668 \\
\hline 5. & $P c=f(L p)$ & 0.600 & 91.06 & 0.957 \\
\hline 6. & $H d=f(L p)$ & 0.749 & 20.09 & 0.556 \\
\hline 7. & $\operatorname{Pr}=f(P d)$ & 0.683 & 19.51 & 0.933 \\
\hline 8. & $P c=f(P d)$ & 0.587 & 102.5 & 0.936 \\
\hline 9. & $\mathrm{Hr}=\mathrm{f}(\operatorname{Pr})$ & 0.491 & 2.343 & 0.166 \\
\hline 10. & $P c=f(\operatorname{Pr})$ & 0.577 & 130.6 & 0.822 \\
\hline 11. & $I c=f(P c)$ & 0.567 & 6.148 & 0.183 \\
\hline 12. & $H d=f(P c)$ & 0.553 & 34.45 & 0.387 \\
\hline 13. & $P g=f(\operatorname{Pr})$ & 0.494 & 90.80 & 0.710 \\
\hline 14. & $P g=f(P c)$ & 0.804 & -12.6 & 0.836 \\
\hline
\end{tabular}

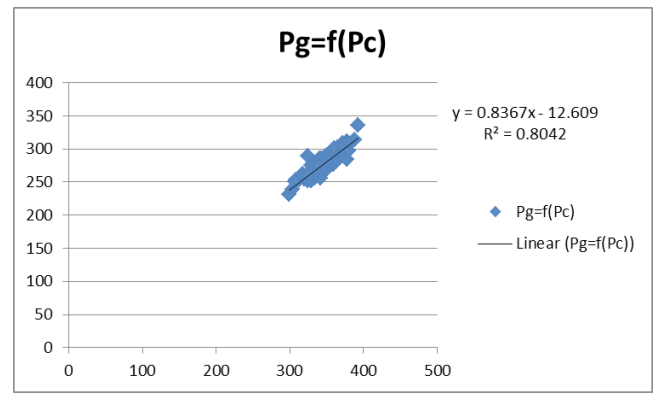

Figure 2. Graphic representation of the simple linear regression equation for correlated variables $\mathrm{Pg}$ and $\mathrm{Pc}$

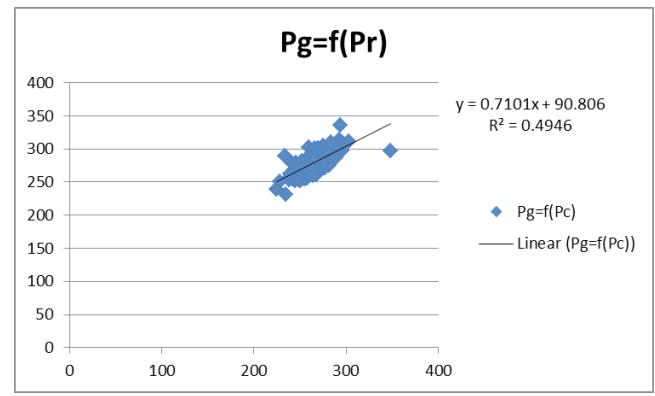

Figure 3. Graphic representation of the simple linear regression equation for correlated variables $\mathrm{Pg}$ and $\mathrm{Pr}$ 


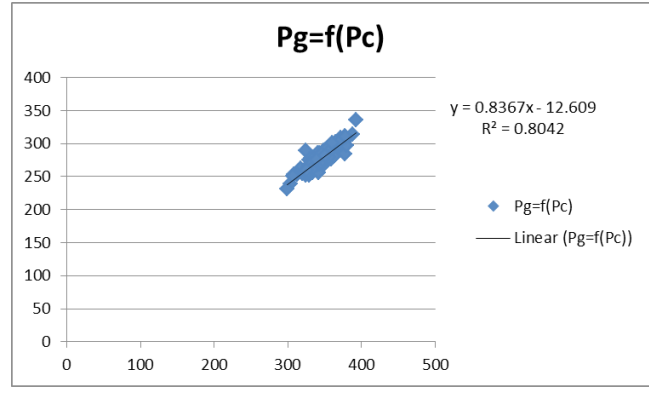

Figure 4. Graphic representation of the simple linear regression equation for correlated variables $\mathrm{Hd}$ and $\mathrm{Pc}$

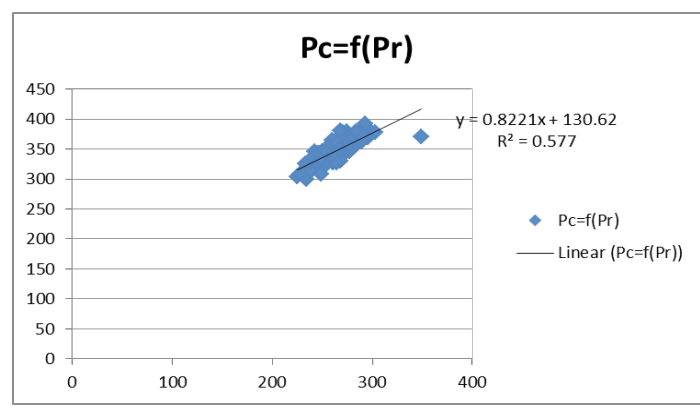

Figure 6. Graphic representation of the simple linear regression equation for correlated variables $\mathrm{Pc}$ and $\mathrm{Pr}$

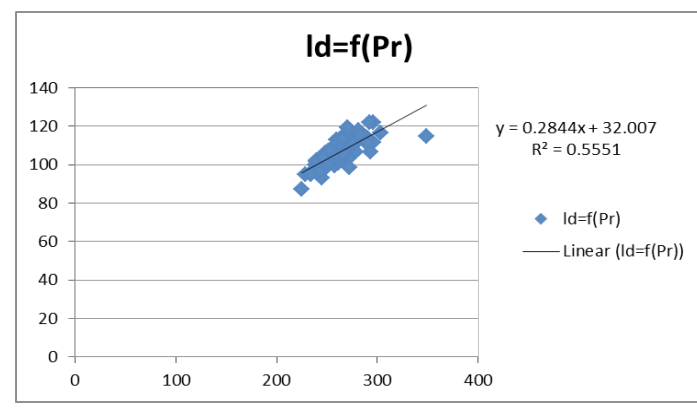

Figure 8. Graphic representation of the simple linear regression equation for correlated variables Id and $\mathrm{Pr}$

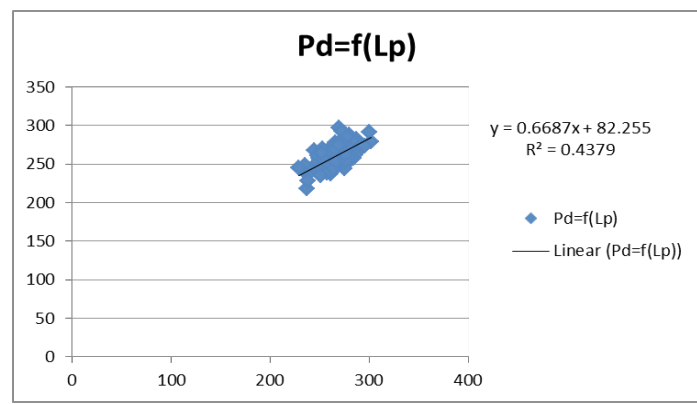

Figure 10. Graphic representation of the simple linear regression equation for correlated variables $\mathrm{Pd}$ and $\mathrm{Lp}$

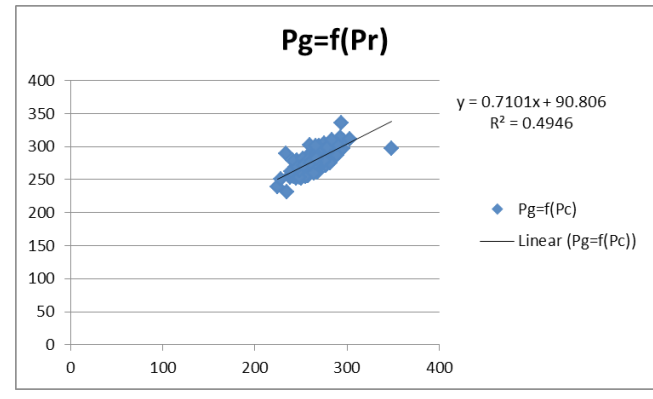

Figure 5. Graphic representation of the simple linear regression equation for correlated variables Ic and Pc

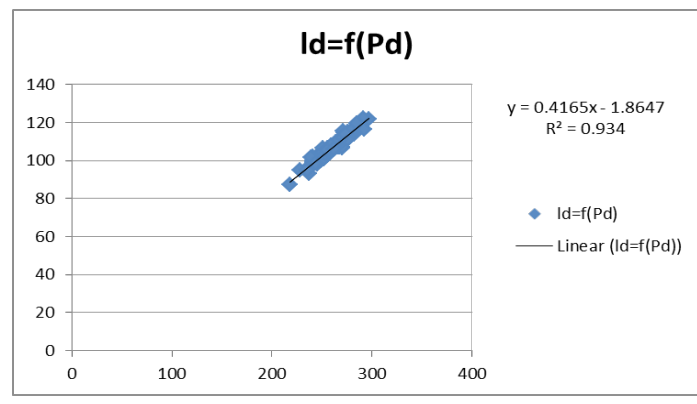

Figure 7. Graphic representation of the simple linear regression equation for correlated variables Id and Pd

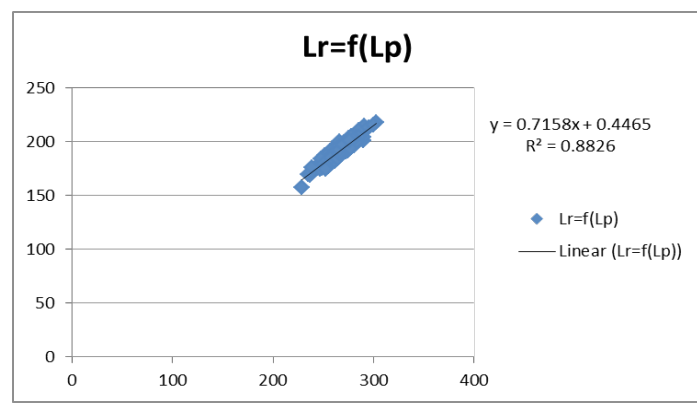

Figure 9. Graphic representation of the simple linear regression equation for correlated variables $\mathrm{Lr}$ and $\mathrm{Lp}$

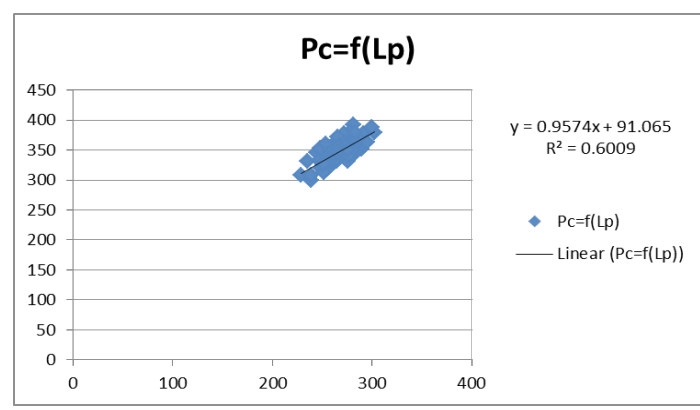

Figure 11. Graphic representation of the simple linear regression equation for correlated variables Pc and Lp 


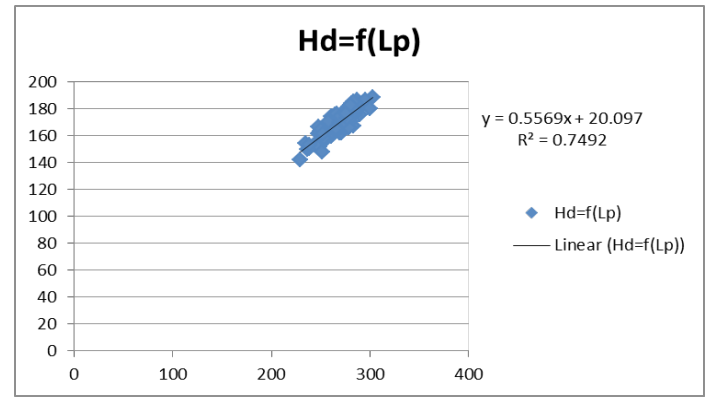

Figure 12. Graphic representation of the simple linear regression equation for correlated variables $\mathrm{Hd}$ and $\mathrm{Lp}$

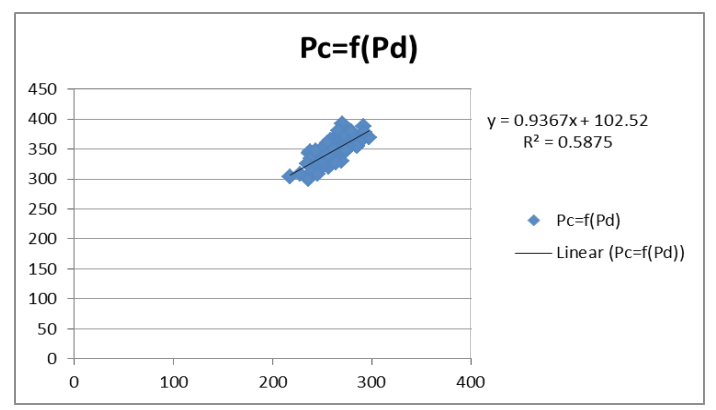

Figure 14. Graphic representation of the simple linear regression equation for correlated variables $\mathrm{Pc}$ and $\mathrm{Pd}$

Multiple Correlations (among Three Variables) to Characterize the Interdependence of Anthropometric Parameters

Intensity of correlation among three variables is represented by the coefficient of multiple correlation $\mathrm{R}_{\mathrm{y \times 1 \times 2}}$ [2-4]:

$R_{y x 1 x 2}=\sqrt{\frac{r_{y x 1}^{2}+r_{y x 2}^{2}-2 r_{y x 1} r_{y x 2} r_{x 1 x 2}}{1-r_{x 1 x 2}^{2}}}$

Table 4 exemplifies the intensity among the following anthropometric parameters: $\mathrm{Pr}$ with $\mathrm{Lp}$ and $\mathrm{Pd}$, Id with $\mathrm{Lp}$ and $\mathrm{Pd}$, Ic with $\mathrm{Lp}$ and $\mathrm{Pd}$. There is a very high correlation of the Id variable with $L p$ and $P d$, represented by the value of the coefficient of correlation $\mathrm{R}_{\mathrm{y \times 1} 1 \times 2}>0.9$. In the case of the Pr variable depening on $L p$ and $\mathrm{Pd}$ and $\mathrm{Ic}$ variable depending on $\mathrm{Lp}$ with $\mathrm{Pd}$, correlations are high, $0.7<\mathrm{R}_{\mathrm{y} \times 1 \times 2}<0.9$.

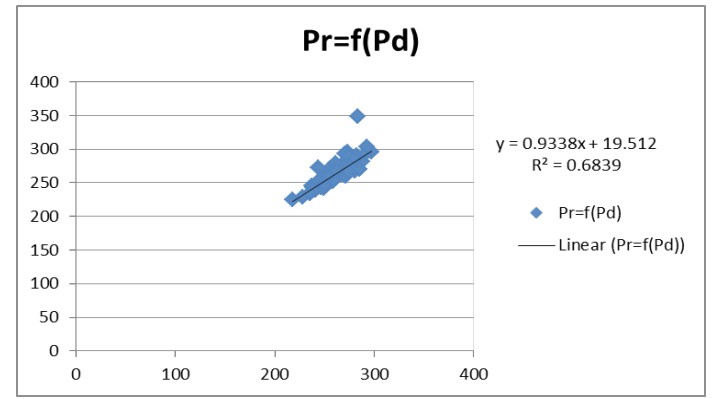

Figure 13. Graphic representation of the simple linear regression equation for correlated variables $\mathrm{Pr}$ and $\mathrm{Pd}$

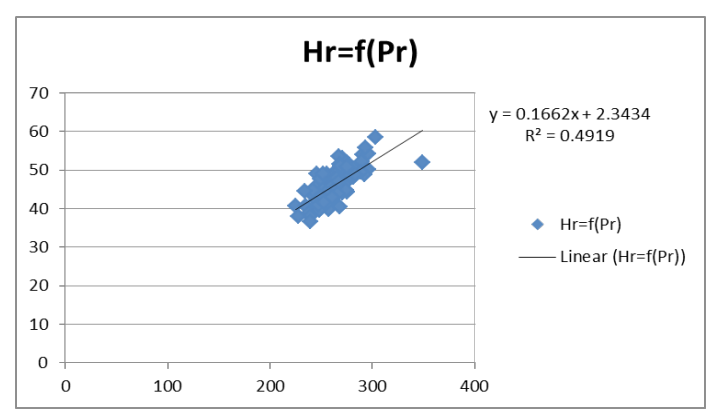

Figure 15. Graphic representation of the simple linear regression equation for correlated variables $\mathrm{Hr}$ and $\mathrm{Pr}$

Table 4: Values of simple and multiple coefficients of correlation

\begin{tabular}{|c|c|c|c|}
\hline Anthropometric parameter & $\begin{array}{l}r_{y \times 1} \\
L p=x_{1}\end{array}$ & $\begin{array}{l}r_{y \times 2} \\
P d=x\end{array}$ & $R_{y \times 1 \times 2}$ \\
\hline$P r=f(L p, P d)$ & 0.602 & 0.765 & 0.832 \\
\hline$I d=f(L p, P d)$ & 0.545 & 0.928 & 0.915 \\
\hline $\mid c=f(L p, P d)$ & 0.654 & 0.755 & 0.789 \\
\hline
\end{tabular}




\section{CONCLUSIONS}

In order to characterize the dependence between two pairs of anthropometric parameters, the simple and multiple linear correlation was verified. For the simple correlation, coefficients of correlation $r_{x y}$ were calculated, and the resulting values were compared with the values presented in the literature to characterize the type of correlation, namely:

- $r_{x y}=0.2-0.4-$ Very low correlation

- $r_{x y}=0.4-0.7-$ Low correlation

- $r_{x y}=0.7-0.9-$ High correlation

- $r_{x y}=0.9-1-$ Very high correlation

This analysis proved the existence of high and very high correlations, as follows:

- Very high correlations are obtained for the following groups of parameters: Id and Pd ( $\left.r_{x y}=0.966\right), L r$ and Lp $\left(r_{x y}=0.939\right)$, Hme and Hsf $\left(r_{x y}=0.954\right)$, $\mathrm{Hmi}$ and $\mathrm{Hs}\left(r_{x y}=0.973\right)$

- High correlations are obtained for $\mathrm{Lp}$ and $\mathrm{Pd}\left(r_{x y}=0.762\right), \operatorname{Pr}$ and $\mathrm{Pd}$ $\left(r_{x y}=0.827\right), \operatorname{Pr}$ and $I d\left(r_{x y}=0.745\right), \mathrm{Hd}$ and $\operatorname{Lp}\left(r_{x y}=0.866\right), \mathrm{Hr}$ and $\operatorname{Pr}\left(r_{x y}=0.701\right), P c$ and Lp $\left(r_{x y}=0.775\right), P c$ and Pd $\left(r_{x y}=0.767\right), P c$ and $\operatorname{Pr}\left(r_{x y}=0.760\right), P c$ and $I c\left(r_{x y}=0.753\right), P c$ and $\mathrm{Hd}\left(r_{x y}=0.744\right), \operatorname{Pg}$ and $\operatorname{Pr}\left(r_{x y}=0.703\right)$, $\mathrm{Pg}$ and $\mathrm{Pc}\left(\mathrm{r}_{\mathrm{xy}}=0.897\right)$.

Simple linear regression equations were determined for the pairs of anthropometric parameters characterized by coefficients of correlation higher than 0.7 (strong and very strong correlations). Of all pairs tested, very strong linear dependences are found, described by the following relationships: $I d=f(P d), I d=f(P r)$, $L r=f(L p), P d=f(L p), P c=f(L p), \quad H d=f(L p), \operatorname{Pr}=f(P d)$, $P c=f(P d), \quad H r=f(P r), \quad P c=f(P r), \quad I c=f(P c), \quad H d=f(P c)$, $P g=f(P r)$. Linear regression equations $(Y=f(x)$, $\mathrm{Y}=\mathrm{b} 0+\mathrm{b} 1 * \mathrm{X})$ may be used in designing lasts to establish dependences among geometric parameters of the last in close connection with the laws of variation of anthropometric parameters of the foot.

Establishing multiple linear correlations proved that there is a very high correlation of the Id variable (foot breadth) with Lp (foot length) and $P d$ (ball girth circumference) (Id=f(Lp, $P d)$, represented by the value of the coefficient of correlation $R_{y x} 1 \times 2>0.9$. In the case of variable $\operatorname{Pr}$ (instep circumference) depending on $\mathrm{Lp}$ (foot length) and $\mathrm{Pd}$ (ball girth circumference) $(\operatorname{Pr}=f(L p, P d)$ and Ic variable (heel breadth) depending on $\mathrm{Lp}$ (foot length) and Pd (ball girth circumference) $(I c=f(L p, P d))$, correlations are high, $0.7<R_{y x} 1 \times 2<0.9$.

\section{Acknowledgements}

This work was financed through PN 1634 04 01/2016 project, supported by the Romanian Ministry of National Education and Scientific Research.

\section{REFERENCES}

1. Pantazi, M., Vasilescu, A.M., 3D Imaging Capture of the Foot and Data Processing for a Database of Anthropometric Parameters, Proceedings of The 6th International Conference on Advanced Materials and Systems - ICAMS 2016, ISSN: 2068-0783, CERTEX Publishing House, Session 3 Innovative Technologies, 2016, 387-392, https://doi.org/10.24264/icams-2016.III.13.

2. Andrei, T., Stancu, S., Statistics - Theory and Applications (in Romanian), ALL Publishing House, Bucharest, ISBN 973-571-108-7, 1995.

3. Malureanu, G., Mihai, A., Fundamentals of Footwear Design (in Romanian), Performantica Publishing House, lasi, ISBN 973-8075-88-2, 2003.

4. Avadanei, M., Theoretical and Experimental Contributions on the Use of Antropometric Data in Designing Clothing Items (in 
Romanian), PhD Thesis, "Gh. Asachi" Technical University of Iasi, 2000.

5. Gheorghiu, D., Statistics Applied in Psychology (in Romanian), Bucharest, "Titu Maiorescu" University Press, ISBN 973-86202-2-8, 2003.
(C) 2018 by the author(s). Published by INCDTPICPI, Bucharest, RO. This is an open access article distributed under the terms and conditions of the Creative Commons Attribution license (http:// creativecommons.org/licenses/by/4.0/). 